\section{Perspectives of fetal dystocia in cattle and buffalo}

\author{
Govind Narayan Purohit, Pramod Kumar, \\ Kanika Solanki, Chandra Shekher and \\ Sumit Prakash Yadav
}

Department of Veterinary Gynecology and Obstetrics, College of Veterinary and Animal Science, Rajasthan University of Veterinary and Animal Science, Bikaner, Rajasthan, India

\section{Abstract}

We review the causes of fetal dystocia in cows and buffalo. Two fetal causes are distinct fetal oversize and fetal abnormalities. Fetal oversize is common in heifers, cows of beef cattle breeds, prolonged gestations, increased calf birth weight, male calves and perinatal fetal death with resultant emphysema. Fetal abnormalities include monsters, fetal diseases and fetal maldispositions, and it is difficult to deliver such fetuses because of their altered shape. Although monsters are rare in cattle, a large number of monstrosities have been reported in river buffalo; yet also here, overall incidence is low. Diseases of the fetus resulting in dystocia include hydrocephalus, ascites, anasarca and hydrothorax. The most common cause of dystocia in cattle seems to be fetal maldispositions, of which limb flexion and head deviation appear to be the most frequent. We provide a brief description of the management of dystocia from different causes in cattle and buffalo. A case analysis of 192 and 112 dystocia in cattle and buffalo, respectively, at our referral center revealed that dystocia is significantly higher $(\mathrm{P}<0.05)$ in first and second parity cows and buffalo, and that dystocia of fetal origin is common in cows $(65.62 \%)$ but less frequent $(40.17 \%)$ in buffalo. In buffalo, the single biggest cause of dystocia was uterine torsion (53.57\%). Fetal survival was significantly $(\mathrm{P}<0.05)$ higher both in cows and buffalo when delivery was completed within $12 \mathrm{~h}$ of second stage of labor.

\section{Introduction}

Dystocia is defined as delayed or difficult calving, sometimes requiring significant human assistance. ${ }^{1-3}$ It has a considerable impact on production and future reproduction of dairy ${ }^{4-8}$ and beef 9,10 cows. It generally has a lower incidence in buffalo but still has a considerable impact on buffalo production (1-2\%).11,12 However, Khan et al. ${ }^{13}$ analyzed the incidence of abnormal calvings in buffalo in various reports and found it to be between $5.6-12.6 \%$ in Murrah, $8.94 \%$ in Jaffarabadi and between 4.6 to $5.4 \%$ in Surti buffalo.

The reasons for such a low incidence in buffalo could be due to anatomical differences between cattle and buffalo. Buffalo have a more capacious pelvis, larger area of ileum, a free and easily separable fifth sacral vertebra, 14 easily dilatable small sized vaginal canal, and elongated and wide apart vulvar lips. ${ }^{15}$ These anatomical differences mean that the first and second stages of labor in the buffalo can easily be completed within 20-70 min.14,16,17

The causes of dystocia have been described from a number of perspectives; either based on analysis of a large number of calving records in dairy $8,18-20$ and beef cows $9,10,21,22$ or on the basis of clinical findings. ${ }^{23-25}$ Most reports of buffalo come from clinical data. $26-28 \mathrm{~A}$ large number of risk factors for dystocia have been identified. 2,4 It has also been recognized that the introduction of large sized beef bulls like Charolais and Simmental ${ }^{10,21,29-31}$ and the Holstein Friesian bulls in dairy cows ${ }^{18,32,33}$ has resulted in an increased incidence of dystocia, probably due to an increase in the body weight of the calf and the change in its shape. Such effects have not been documented for buffalo. A common finding in most studies is that dystocia is more frequent in the primiparous heifers $3,9,19,20,34,35$ and that fetopelvic disproportion is the main cause of dystocia in heifers, whereas fetal maldispositions are common in pleuriparous cows. ${ }^{33}$ The two major determinants of fetopelvic disproportions are calf birth weight and maternal pelvic size. $33,35,36$ Many authors have described the causes of increased fetal weight $6,8,10,19,37$ and attempts to reduce the incidence of dystocia have also been mentioned.35,38-41 This study analyzes the causes of fetal oversize and the fetal abnormalities causing dystocia in cattle and buffalo, and their management. A critical evaluation is also made of the type of cases presented at our referral center.

\section{Fetal dystocia}

Studies on cattle indicate that the fetus is the major cause of dystocia ${ }^{23-25,42,43}$ and abnormal fetal presentations at birth contribute to 1 $5 \%$ of total dystocia cases.22,44,45 In contrast, fetal origins of dystocia are less frequent in buffalo. ${ }^{27}$

Broadly speaking, the fetal origins of dystocia in cattle can be divided into those caused by excessive fetal size relative to the maternal pelvis (fetopelvic disproportion) and those caused by abnormalities of the fetus (fetal monsters, fetal diseases and fetal maldisposition). 46,47 Thus, in this study, fetal dystocia is
Correspondence: Govind Naravan Purohit, Department of Veterinary Gynecology and Obstetrics, College of Veterinary and Animal Science, Rajasthan University of Veterinary and Animal Science, Bikaner, Rajasthan, 334001 India.

E-mail: gnpobs@gmail.com

Key words: buffalo, cattle, dystocia, fetal oversize, fetal maldisposition.

Conflict of interests: the authors report no conflict of interests.

Received for publication: 30 September 2011. Revision received: 2 November 2011.

Accepted for publication: 28 November 2011.

This work is licensed under a Creative Commons Attribution NonCommercial 3.0 License (CC BYNC 3.0).

(C) Copyright G.N. Purohit et al., 2012

Licensee PAGEPress srl, Italy

Veterinary Science Development 2012; 2:e8 doi:10.4081/vsd.2012.e8

reviewed according to fetal oversize and fetal abnormalities.

\section{Fetal oversize}

The most common cause of dystocia in cattle is fetopelvic disproportion. 46,48 This is most common in heifers when the fetus is of normal size for its breed but the maternal pelvis is not big enough, or the fetus is unusually large and cannot be delivered through a pelvic canal of normal size. ${ }^{46}$ Mating between various breeds of cows may result in an increased incidence of dystocia due to fetopelvic disproportion. $.99,50$ Dystocia rates vary enormously between individual bulls of the same breed and this difference is many times greater than that which exists between breeds. ${ }^{50}$ Similar differences are possibly also seen in buffalo. Birth weight, double muscling, maternal nutrition and pelvic capacity all affect fetal delivery and must be taken into consideration. Dystocia in double muscled cows is caused by the modified calf morphology that is induced by the muscular hypertrophy. ${ }^{51}$ Thus, cesarean deliveries are required for $89.5 \%$ of the parturitions in Belgian Blue cows. ${ }^{52}$ Excessively large sized fetuses can occur with prolonged gestation periods and such conditions are likely to occur with prolonged progesterone therapy, especially during mid- or late gestation. 53 0versized fetuses cannot be delivered normally and, therefore, the decision to relieve dystocia either by fetotomy or cesarean delivery would depend on the condition of the fetus and/or the dam. Grossly oversized fetuses in a narrow birth canal must be removed by cesarean section. An attempt can be made to remove dead 
oversized fetuses in a relaxed birth canal by fetotomy but if this fails, caesarean section is the last resort.

There are various reasons for fetal oversize, such as calf birth weight, calf sex, twins, and fetal death and emphysema. Some of these are described here.

\section{Calf birth weight}

A large number of studies conducted on dairy $3,8,19,35$ and beef 10,54 cows point out that the calf birth weight, especially in 2-year old first calving heifers, significantly affects the difficultly in calving. In Holsteins, a $1 \mathrm{~kg}$ increase in calf birth weight increased the probability of dystocia by $13.0 \% .19$ The breed of the sire and the dam, along with genetic traits of both parents, play the most important role in determining birth weight. ${ }^{36}$ Since birth weight is to some extent inheritable, the selection of bulls with low birth weights would be advantageous, but this would reduce subsequent growth rates. Attempts to modify birth weights of calves at calving without altering their subsequent growth rates have aimed at identifying the expected progeny difference (EPD) by using different bulls in the same breed. However, such attempts are expected to reduce, but not eliminate, difficulty in calving. Because EPDs are not comparable across breeds, selection of a sire on the basis of a low or negative EPD for birth weight may not be reliable if the heifer and sire are of different breeds. 46

A few studies have observed that a large number of sires of two beef breeds (Charolais and Simmental) ${ }^{29-31,34}$ and one dairy breed (Holstein) $3,18,33$ contributed to an increased incidence of dystocia due to heavy birth weight of their calves, whereas Angus and Jersey breed sires reduce the incidence of dystocia due to lower calf birth weights. ${ }^{31,55}$

A comparatively novel aspect of fetal oversize is the large offspring syndrome in which a calf is the result of in vitro embryo production technologies.56 Embryos are exposed to a variety of unusual environments during their growth which results in gross abnormalities of several organs, including increased muscle mass and alterations in muscle fibre. 57 The most striking feature of the syndrome is the large size of these calves at birth, resulting in increased frequencies of calving difficulties. 58

In buffalo, fetal causes of dystocia are less frequent 27,59 and, surprisingly, in one study, dystocia was less frequent in primiparous (21.13\%) compared to multiparous (78.87\%) buffalo. ${ }^{60}$ Buffalo are older at first calving, ranging from 36-52 months in different breeds. ${ }^{61-66}$ This provides greater time for the pelvis of first calving heifers to develop. Moreover, calves born to second parity buffalo are heavier than all other parities ${ }^{67}$ and the average birth weight of buffalo calves is lower compared to Friesian cows. ${ }^{64}$ Therefore, birth weight is a less frequent cause of dystocia in buffalo. However, there are no data available comparing breeding of heavier breeds, like Murrah or Nili Ravi, with the smaller breeds, like Surti, regarding the incidence of dystocia and calf birth weight.

\section{Sex}

Male calves are known to require more assistance at calving compared to female calves. $18,19,21,28,34$ In addition, gestations with male calves are longer, which also influences the risk of dystocia. ${ }^{68}$ Holstein male calves had a $40.0 \%$ higher incidence of dystocia. 69 The rate of dystocia for male and female calves differs between heifers and cows.70 A few studies 22,30 have, however, observed that sex of the calf had little influence on dystocia in cows. The causes of dystocia are complex, and no more than $50 \%$ of the total variation in dystocia can be explained by factors that can be defined or measured. 41

\section{Twins}

In general, multiple calvings are more difficult than single ones. ${ }^{2,8}$ Cows with twins have a shorter gestation length and more dystocia.71,72 Twin calves are known to be lighter in weight compared to single births. ${ }^{73}$ However, the higher incidence of dystocia with twin births is due to malpresentation of one fetus 73 or simultaneous presentation of both fetuses. ${ }^{74-76}$ Twins also reduce the breeding efficiency of dairy and beef cows. ${ }^{77}$ Twin calvings in Holsteins resulted in 10.5 times higher probability of dystocia compared to single calvings. ${ }^{69}$ Jersey and Holstein Friesian cows showed a similar trend. 6 The presence of simultaneous presentation of twin pregnancies should be diagnosed carefully, also to avoid misinterpreting monsters as twins, and one fetus should be repelled while the other is delivered by traction.

\section{Fetal death and emphysema}

It is difficult to show univocally whether intrauterine fetal death leads to dystocia or dystocia increases the chance of stillbirths. ${ }^{78}$ It is thought that the death of a calf before the start of expulsion significantly increases the risk of malpresentation.2 According to Johanson and Berger, 19 49\% of perinatal mortality was associated with unassisted births. Fetal death may result in an increase in fetal size due to putrefaction of the fetus and accumulation of gases in the subcutaneous tissue in the following 24-72 h. ${ }^{27}$ This is known as fetal emphysema.

Emphysema is the sequel of all conditions resulting in fetal death or uterine inertia. It has also been observed in prolonged cases of uterine torsion and septic metritis. Fetal emphysema should always be suspected in prolonged cases of dystocia exceeding over $24 \mathrm{~h}$.
After such prolonged cases, abdominal contractions are weak and intermittent for a few hours and then cease completely.27,79 Fetid watery discharge may be seen and the vaginal mucus membrane is usually dry, swollen and inflamed. The uterine wall may be tightly contracted around the fetus and the cervix may also be contracted, especially in cows and less often in buffalo. The fetus is dead and swollen, and the crepitating feel is readily palpable. It may often be difficult to palpate the position and presentation of the fetus due to swollen limbs. Fetal emphysema is found fairly frequently in buffalo but reports are available only for river buffalo. ${ }^{79}$ Invasion by microorganisms from the vagina is the common cause of emphysema in dead fetuses.

In these cases, prognosis is reserved because of the possible complications. ${ }^{27}$ If the fetus is presented properly and in the correct position, large quantities of lubricant should be infused and the fetus removed by traction. In fetal maldispositions, it may be necessary to relieve the gas by deep incisions and/or partial fetotomy (which is easier) followed by correction of position and removal of the fetus by traction. Care and attention should be given to the general condition of the dam before handling. Cesarean section should only be considered as a last resort because of the potential dangers of developing peritonitis.

\section{Fetal abnormalities}

\section{Fetal monstrosities}

Mild developmental abnormalities of the ovum, embryo or fetus result in structural abnormalities in the fetus leading to monstrosities. Organic deviation in either structure or form or both, in one or several parts of the body, is known as monster. Most of the anomalies occur in early stage of cell differentiation when the conceptus is subjected to genetic and maternal influences. Hereditary defects due to autosomal recessive genes are common. Monstrosities are common in the buffalo. The incidence of monstrosities reported for cow is $0.5 \%, 80$ whereas an incidence of $7.9 \% 26$ to $12.8 \% 81$ has been reported for river buffalo. Most of the monstrosities reported in buffalo are related to river buffalo; there are very little data available on swamp buffalo.

Fetuses with congenital defects are dead at birth, and anomalies of muscular skeletal and nervous systems are common in monsters. Dystocia due to monsters is usually relieved by cesarean section since fetotomy is of limited usefulness except in a few monsters. A large number of monstrosities have been reported both in cattle and buffalo but not all result in dystocia. It may be difficult for monsters to pass through the birth canal, either because of their altered shape or because of their relative size. The common monsters causing dystocia 
are Schistosoma reflexus, Perosomus elumbis, Double or conjoined monsters and Cyclopia.

\section{Schistosoma reflexus}

This type of monster presents acute angulations of the vertebral column causing dorsal approximation of the head and tail. The main defect is skeletal, and the thoracic and abdominal tunics are absent or incomplete, ventrally exposing the visceral contents. ${ }^{82}$ Diagnosis is based on the presence of fetal viscera, all the four legs, head and tail in the vaginal passage. The vertebral column presents a twisted appearance. Since the condition is hereditary, further breeding of the dam from the same sire is not advisable. ${ }^{82,83}$ The incidence of Schistosomus reflexus as a cause of bovine dystocia in South Western Victoria was described to be $1.3 \% .84$ Schistosoma reflexus has been recorded in births of twin bovine offspring. $84-86$ Such monsters have been reported in cattle ${ }^{87-97}$ and river buffalo. ${ }^{81,98-102}$ The calves may sometimes be delivered manually. 87,99 The exposed abdominal organs of the Schistosoma fetus, especially the intestines, should not be confused with the maternal intestines that are much bigger in size. Adequate lubrication of the birth canal is essential in the delivery of such fetuses. Partial fetotomy of the fetal parts is suggested if the spinal curvature is acute preventing passage of the fetus through the birth canal. ${ }^{103}$ If this is not possible, a cesarean is required.101

\section{Perosomus elumbis}

Such monsters have been reported in cows $96,104-106$ as well as riverine buffalo ${ }^{107,108}$ and considered to be a congenital anomaly of unknown etiology. ${ }^{109}$ The hind limbs of the fetus are very rigid which results in dystocia. 53 The monster usually shows congenital abnormality of the skeletal system. The lumbar and sacral regions are badly developed. There may be deformed pelvis and arthrogryposis of limbs. The primary abnormality is, however, hypoplasia of the spinal cord. It is difficult to deliver the fetus in cows manually but this is sometimes achieved in buffalo. ${ }^{107}$

\section{Double or conjoined monsters}

These consist of two fetuses joined together. They usually arise from a single ovum and are considered monozygotic. They are the most common type of monsters. Conjoined twins are also known as diplopagus monsters or Siamese twins. These twins also arise from a single ovum and are monozygotic. They are the result of incomplete division of a fertilized ovum and show great variation from partial duplication to almost complete separation of two individuals, joined in just a few places. A wide variety of conjoined twins have been described in cattle and buffalo.110-121

Either cranial or caudal parts of the body may be duplicated, the former being more com- mon. The duplicated parts and increased number of limbs result in dystocia. Different terminologies are used to describe the monsters according to how many parts are duplicated and the number of places at which the fetuses are joined.122 Thoracopagus means fusion at thorax. Conjoined twins with symmetrical components or component parts are called Diplopagus monsters or Siamese twins. Conjoined twins are common in cattle and equally common in buffalo (Table 1).123-178 Conjoined twins can have all components nearly complete and these include thoracopagus (twins joined at or near sternum), Pygopagus (twins connected at sacrum), Craniopagus (twins united at heads) and Ischiopagus (twins joined at pelvic region and heads in opposite directions). Partial duplication of the cranial and caudal parts of the conjoined fetuses can occur. Monocephalus monsters have partial duplication of the frontal region, nose and mouth, and are called diprosopus or double face. Dicephalus monsters have two heads whereas dipygus monsters have duplications in the caudal region. Terms used to indicate the extra number of cranial limbs (forelimbs) are dibrachuis (two pairs of limbs), tribrachius (three pairs of limbs) tetrabrachius (four pairs of limbs), whereas the terms dipus (two pairs) tripus (three pairs) and tetrapus (four pairs) are used to describe duplicacy of hind limbs. The majority of the conjoined monsters are dead during dystocia and hence efforts to relieve dystocia in these cases should aim at fetotomy with caesarean section adopted as a last resort. ${ }^{179}$ Grossly over enlarged and emphysematous monstrosities are extremely difficult to relieve by fetotomy and hence caesarean section should be performed. Table 1 shows the methods used to remove different monsters in various reports.

\section{Cyclopia}

Cyclopia has been described in cattle ${ }^{180-185}$ and rarely in river buffalo. 104 The fetus is usually dead and has a single orbit and eyeball in the central head region. There is elongated soft tissue growth in the lower jaw region of the monster. Cyclopia is described as occurring due to malformations of a non-genetic nature. The body parts of the fetus are small 182 and fetuses can, therefore, be removed manually. 181,183 They are rarely born co-twin to a normal calf.

\section{Fetal diseases}

Various diseases of the fetus can result in the altered shape of the fetus and dystocia in cattle and buffalo. These include hydrocephalus, ascitis, anasarca, hydrothorax, and tumors.

\section{Hydrocephalus}

The condition has been described both in cows ${ }^{186-200}$ and buffalo. ${ }^{195,201-203}$ There is accumulation of excessive fluid in the ventricles of the brain or dura matter. Hydrocephalus is either external or internal. In the external hydrocephalus, ${ }^{204}$ fluid accumulates in the subarachnoid space exterior to the brain whereas in the internal hydrocephalus, ${ }^{94}$ fluid accumulates in the ventricles of the brain. Death of the fetus is due to pressure on vital centers of the brain. The frontal, temporal and parietal bones are usually involved becoming deformed, separated and thin. The condition does not affect fetal development but may result in death of the fetus at birth or soon after birth. In cattle, a simple autosomal recessive gene and autosomal dominant gene with incomplete penetrance has been known to be associated with hydrocephalus. In a few cases reported in buffalo, alopecia of the head region was evident. Diagnosis of the condition is easy if the fetus is in anterior presentation. In fetuses with very large heads, puncture of the head with a trochar is advocated to relieve dystocia, along with routine obstetric maneuvers. ${ }^{202}$ Sometimes, the calf may be born normally 204 or by caesarean section when required.139,194,201

\section{Ascites, anasarca and hydrothorax}

Ascites is dropsy of the peritoneum. ${ }^{205}$ Anasarca is general dropsy of tissues under the skin ${ }^{206-208}$ whereas hydrothorax is the accumulation of fluid in the thoracic cavity. The exact causes of these conditions are not known but derangement of fetal circulation/obliteration of fetal lymphatics usually results in anasarca and diminished urinary excretion in ascites. Uterine disease or related factors may also play a role. Fluctuating swellings and edema may be palpable per vaginum at the time of delivery. Such calves are generally dead when born and may be weak if born alive. To relieve dystocia, fetotomy or puncture may be performed if the fetus is dead. Both ascitic and anasarcous fetuses have been reported to cause dystocia in cattle 209-212 and riverine buffaloes. ${ }^{213-219}$ Many of the abnormal fetuses were delivered by abdominal puncture $211,214,216$ or by caesarean section. ${ }^{210,216}$

Cystic enlargement of the urinary bladder of the fetus has been recorded.220 Some studies have reported achondroplastic (bull dog) calves both in cattle $221-225$ and buffalo. ${ }^{81,226,227}$ In such monsters, the head is enlarged but limbs are short.

Other less significant monsters have been recorded, including holocardius acardius monsters recorded in cattle 228,229 and buffalo. ${ }^{26,230-232}$ These monsters are born co-twin to a normal calf and are considered asymmetrical twins. The monsters are composed of outer skin enclosing a mass of fat. Mohan et al.228 record- 
ed a compylorrachis fetal monster with lateral curvature of the spine delivered manually in a cow. Buffalo fetuses with muscular hypertrophy and excessive abdominal fat caused dystocia in buffalo but vaginal delivery was achieved with assistance.233-235 Likewise, buffalo fetus with arthrogryposis was relieved by partial fetotomy.236 Fetal anencephaly has been reported to develop in 125-day bovine fetuses by inoculation of Blue tongue virus. ${ }^{237}$ Similarly BVD virus is known to result in congenital malformations in calves. ${ }^{238}$ Tumors of the fetus are a very rare cause of dystocia, and are only significant when they are large in size ${ }^{238}$ and present on the external body surface of the fetus. Likewise, polysarca, the accu- mulation of excessive fat in the subcutaneous tissue, has also been rarely described. 53

\section{Fetal maldispositions}

In recent literature on equine obstetrics, ${ }^{239,240}$ the term fetal maldispositions has been suggested to imply any combination of abnormalities in presentation, position and/or posture,

Table 1. Reported methods of delivery of fetal monsters in cattle and buffaloes.

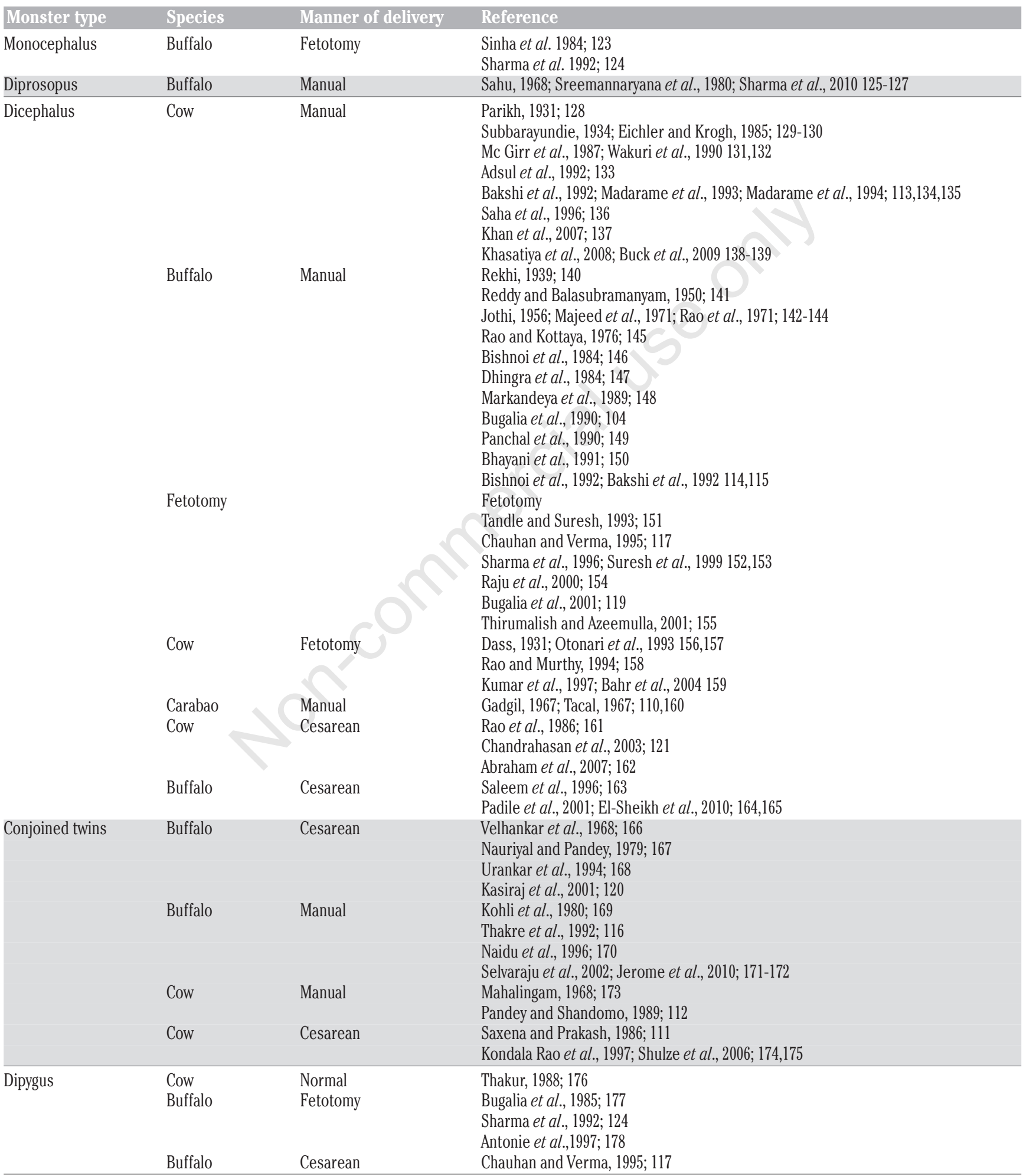


and the authors feel that the same term should be used in all veterinary obstetrics literature. Therefore, the term has been used in the present review to represent any abnormality in presentation, position and posture. Similarly, the terms used here, such as cranial and caudal presentation, appear to be more appropriate than anterior and posterior presentation as previously suggested. 240

Various types of fetal dystocia due to fetal maldispositions have been reported in cattle and buffalo. It is thought that these are probably due to reduced viability of the offspring. Failure of the fetus to rotate from the intrauterine position to the normal parturient position may result in dystocia. The cranial presentation of fetuses is assumed to be no later than 216 days of gestation in normal pregnancies. $^{241}$ Parts of the fetus may get jammed at the pelvic brim leading to flexion/ rotation of the part involved and subsequent dystocia. Furthermore, transverse presentations and adhesions of the fetus invariably result in dystocia. The normal parturient presentation and position assumed by the normal fetus at the time of delivery is the cranial presentation dorso-sacral position with extended forelimbs and head resting on metacarpal bones. Any presentation or position other than this is likely to cause dystocia. The heritability of malpresentation was low (0.17) for Hereford and zero for Angus cows. ${ }^{21}$ The caudal dorsal presentation was found to be the most frequent malpresentation, and limb flexion in cranial presentation, head deviation, breech, post ventral, transverse and ventro vertical presentation were $11.4 \%, 2.5 \%, 8.2 \%, 1.3 \%$, $1.3 \%$ and $0.6 \%$, respectively, in this study. ${ }^{21}$

Abnormal positions and postures are described for cranial (anterior) and caudal (posterior) presentations separately. The total incidence of dystocia due to fetal maldispositions described for the buffalo vary from $45.4^{26}$ to $69.8 \% .60$ In dairy cattle, Wehrend et al. ${ }^{43}$ have observed that incorrect fetal orientation of a dead fetus was the most frequent cause (38.9\%) of dystocia and similar findings were recorded by Holland et al. ${ }^{21}$ in beef cows.

\section{Cranial (anterior) presentation}

All the abnormal positions, such as the dorsopubic or dorsoillial, result in dystocia. The position is corrected by retropulsion using manual or mechanical rotation of the fetus. An anterior calving is usually easier than a posterior one. Nix et al.22 recorded that abnormal presentation accounted for only $1 \%$ of the total number of calvings. However, amongst these cases, $70 \%$ were posterior presentations, while $30 \%$ were head and leg deviations. Bennett and Gregory 44 observed 3\% of malpresentation in beef cows. Menard (242) observed the different kinds of malpresentation as: $27.5 \%$ head deviation and the same number of breech pre- sentations, $23.5 \%$ dorsopubic presentation, $7 \%$ forelimb retention, $3.4 \%$ hock flexions and $1.3 \%$ transverse presentations.

In clinical studies on cows in Iraq, the incidence of fetal dystocia was $68.1 \%$ compared with $31.9 \%$ maternal dystocia. The proportions of malpresentations in the cranial and caudal presentation were $51.7 \%$ and $16.3 \%$, respectively. In studies by Garrousi ${ }^{45}$ using data of 2,140 calvings of Iranian HF cows, malpostionings of the fetus were observed in $5.04 \%$ of the calvings. Clinical studies on cows in Brazil found fetal dystocia was predominant (77.42\%) compared to maternal dystocia. Malposition, fetal malformations and caudal presentations accounted for $46.77 \%, 3.22 \%$ and $17.24 \%$ of the cases of dystocia. ${ }^{25}$

In buffalo, many studies have reported that maternal dystocia is common compared to fetal dystocia ${ }^{27,59}$ whereas others point out a higher number of dystocia of fetal origin. ${ }^{60,81}$ Studies have also shown that cranial presentation malpresentations are common in buffalo dystocia $(80-85 \%) .27,60$

\section{Flexion of forelimbs}

Deviation of forelimbs is the most common cause of dystocia due to fetal malpresentation in cattle and buffalo. When a portion of forelimb is caught in the pelvic inlet, it is forced backwards towards the body due to the contractions, resulting in dystocia due to an increase in the pectoral diameter. Flexion of one or both forelimbs at the knee (carpal flexion) is common in dystocia in cows and buffalo. Other conditions include incomplete extension of elbows and complete retention of one or both forelimbs (shoulder flexion).

Carpal flexion and lateral head deviations are the most common forms of maldispositions in cranial presentations of the fetus resulting in dystocia in cattle and buffalo. ${ }^{53}$ Most of the abnormal presentations, positions and postures described for cattle are seen in the buffalo, but described mostly in river buffalo. In an analysis of 116 clinical cases of dystocia in local Iraqi breeds of cattle, $51.7 \%$ of dystocia were in anterior presentation ${ }^{24}$ of which most were head deviation and limb flexion. Purohit and Mehta ${ }^{27}$ observed 19.4 and $16.9 \%$ cases of limb flexion in clinical cases of dystocia in cattle and buffalo, respectively, whereas Srinivas et al. ${ }^{60}$ observed $57.78 \%$ cases of limb flexion in buffalo dystocia.

\section{Hind limb flexion in cranial presentation}

The hind limb flexion of a fetus in cranial presentation can result in dystocia due to extension and retention of hind limbs at the stifle (hip lock) or the flexed hind limbs passing into the maternal pelvis (dog sitting posture). Hip lock occurs when the head and thorax of the fetus are out of the pelvic brim but stifles obstruct the pelvis. The condition can be corrected by pushing the fetus back to disengage the pelvis followed by oblique traction to clear one stifle from the pelvic brim first. Undue pressure without pushing the pelvis back should be avoided and adequate lubrication must be provided in the birth canal. In our previous study, no such case was recorded. ${ }^{27}$

The dog sitting posture (ventrovertical presentation) is rarely seen and the flexion of the hind limbs is to an extent in which the fetus is practically vertical and hind limbs appear at the birth canal along with the forelimbs. ${ }^{21}$ The condition can be diagnosed by the presence of the head and all four limbs at the birth canal with only the head and shoulders passing through the vulva. ${ }^{122}$ Dystocia can be relieved by fetotomy/bisection of the fetus ${ }^{43}$ or by caesarean section in difficult cases. It is usually extremely difficult to push the flexed hind limbs back, especially in longstanding dystocia in cows. The incidence of the dog sitting posture recorded at our center was $0.52 \%$ in cattle and zero in buffalo over a period of fifteen years. ${ }^{27}$ A similar incidence of $0.6 \%$ was recorded elsewhere. ${ }^{21}$

The abnormal positions of the limbs can usually be corrected manually using sufficient lubrication and it is necessary to cup the hoof of the calf in the palm of the hand while extending the limb to prevent injury to the birth canal. Shoulder flexion should first be converted to a carpal flexion by traction on the flexed limb. The carpal flexion is then corrected by grasping the hoof of the fetus in the cupped hand. However, if the fetus is dead and emphysematous, or if ample space is not available in the pelvic canal, it may be necessary to amputate parts of the fetus, followed by correction and delivery by traction. ${ }^{2} 6$

\section{Deviation of the head}

Deviations of the head, although less common in buffalo than cows, ${ }^{27}$ are more serious causes of dystocia than dystocia due to forelimb deviation. The most common deviation of the head is the lateral deviation; 27 other deviations such as upward or downward deviation are rarely found. The deviation is known to occur due to deflection of the nose against a partially open cervix, and with the progressive contractions of the uterus, the deviation may further increase. 243 When the deviations are slight and the fetus alive, the head can be brought to its normal position with manipulation, but there is a less positive prognosis when the fetus is dead and deviations are due to muscle contractures. Lateral deviation can be corrected by bringing the head into a normal position after repulsion and by using hooks and snares. In difficult cases, partial fetotomy may be performed. ${ }^{26}$ Various options can be considered according to the individual case and the obstetrician's decision may depend on the space available in the pelvic 
canal, the presence of emphysema and rigidness of the neck. In previous studies, the incidence of head deviation recorded varied from 2.5-20.4\% in cows ${ }^{21,22,27}$ and from $7.5-12.2 \%$ in buffaloes. ${ }^{27,60}$ Two types of downward deviations are usually described. In the first, the nose of the fetus is towards the trachea and poll at the pelvic inlet (vertex presentation), and in the second, the entire head is dropped between the forelimbs (Nape presentation). Correction of the first type is easy, especially if the fetus is alive, and can be achieved by grasping the muzzle or nose. Correction of the second type is more difficult and may be attempted by repulsion of fetus. When manipulation of the fetus is not possible, fetotomy may have to be performed. ${ }^{43}$ In difficult cases in the presence of a live fetus, caesarean section is advisable. Upward deviation of the head is rarely possible in cattle and buffalo.

\section{Caudal (posterior) presentation}

Caudal presentations usually culminate in dystocia, except when the fetus is in a dorsosacral position with both the hind limbs completely extended, although some assistance may still be required. During the delivery of a fetus in cranial presentation, the head of the fetus exerts maximum pressure on the birth canal facilitating its final dilation. Since this does not happen in a caudal presentation, the likelihood of dystocia is increased. The higher incidence of fetal mortality in caudal presentations is presumably due to asphyxiation of the fetus subsequent to rupture or compression of the umbilical cord. Any position other than dorso sacral may result in dystocia. Both dorso pubic and dorso illial positions can occur in caudal presentation and correction may be achieved by rotating the fetus. A Dorso pubic position should be taken very seriously and handled with care since parts of fetal limbs can lacerate the maternal, vaginal or rectal wall. The presence of uterine torsion should be excluded before rotating a fetus and ample lubrication must be used during rotation. It is always safer to opt for a timely cesarean section, especially when there is little room for rotation of the fetus in the birth canal. Previous studies recorded the incidence of caudal presentation dystocia in dairy cows to vary from $3.8-17 \% .4,24,27$ In beef cows, $8.2 \%$ cases of breech presentation was seen in $8.2 \%$ and posterior ventral presentations in $1.3 \%$ of cases recorded by Holland et al.,21 whereas Nix et al. ${ }^{22}$ recorded only one breech presentation out of 20 abnormal births. In buffalo, the incidence of caudal presentation dystocia varied from $5.7-13.3 \% .27,60$

\section{Incomplete hind limb extension}

Incomplete extension of the hind limbs in a caudal presentation can occur at the stifle, hock (hock flexion posture) and hips. Bilateral hip flexion in caudal presentation is known as breech presentation whereas unilateral hip flexion is referred as hip flexion posture.

Hock flexion is common in comparison with other deviations and correction is easy. However, care should be taken when making manipulative corrections in a caudal presentation. ${ }^{27}$ The fetus is pushed forward, the hoof is grasped and the limb flexed. The hoof should be pulled medially and the foot drawn back in an arc. The hoof is then lifted over the pelvic brim and extended into the vaginal passage. The same procedure is repeated on the other limb and after correction the fetus is removed by traction. Breech presentation can be diagnosed by the presence of the tail and buttocks in the pelvic cavity.43,122 It is one of the most difficult postures to manage, especially if the fetus is dead. The fetus is pushed forward and upward to bring the hocks nearer to the operator to convert the presentation to a hock flex- ion posture and then correction is made accordingly. Bisection of the pelvis to remove one limb may be attempted in order to relieve dystocia. Epidural anesthesia and raising of the hind limbs are necessary to make the correction. Caesarean section may be performed in difficult cases.

\section{Transverse and vertical presentation}

Transverse presentation is characterized by the presence of the convex dorsum of the fetus facing the cervix. It can be transverse dorsal and transverse ventral. Ventral presentation is identified by the presence of the head and all four limbs in the pelvic canal. This condition should be differentiated from monsters and twins. These two presentations are rarely, if ever, encountered in cattle and buffalo. Although two studies evaluating calving records of beef and dairy cows recorded an incidence of transverse presentations to be $1.3 \%, 21,232$ similar findings in other studies are scarce. Theoretically, the fetus must be corrected by conversion to cranial or caudal presentation. One end of the fetus is repelled while traction is applied on the other end. This is extremely difficult under practical situations, especially in a narrow birth canal, and therefore caesarean section must be performed to deliver the fetus.

In the vertical presentation, the fetal body is lying vertically across the pelvic inlet. The dog sitting position form of vertical presentation is extremely rare in cattle and can be due to faulty traction on hind limbs by inexperienced operators. The situation must be suspected if the head and shoulders of the calf have been delivered but no further progress is possible. The fetus must be repelled back using a crutch repeller, but this is possible only if the birth canal is sufficiently dilated, otherwise caesarean section is advisable.

Table 2. Proportion analysis according to parity, proportion live fetuses from time since dystocia onset and cause of dystocia in cows $(n=192)$ and buffaloes $(n=112)$. Referral cases Gynaecology outdoor, Veterinary College, Bikaner, Rajasthan, India from $1996-2010$.

\begin{tabular}{|c|c|c|c|c|c|c|c|c|}
\hline \multirow[b]{2}{*}{ Parity } & \multicolumn{4}{|c|}{ Cattle } & \multicolumn{4}{|c|}{ Buffaloes } \\
\hline & $\begin{array}{c}\text { I } \\
32.3 \%\end{array}$ & $\begin{array}{c}\text { II } \\
30.2 \%\end{array}$ & $\begin{array}{c}\text { III } \\
14.5 \%\end{array}$ & $\begin{array}{c}\text { Above III } \\
22.9 \%\end{array}$ & $\begin{array}{c}\text { I } \\
30.4 \%\end{array}$ & $\begin{array}{c}\text { II } \\
33.9 \%\end{array}$ & $\begin{array}{c}\text { III } \\
18.7 \%\end{array}$ & $\begin{array}{c}\text { Above III } \\
17.0 \%\end{array}$ \\
\hline Fetal survival & $\begin{array}{l}\text { Upto } 12 \mathrm{~h} \\
81.96 \%\end{array}$ & $\begin{array}{l}12-24 \mathrm{~h} \\
14.75 \%\end{array}$ & $\begin{array}{c}24-36 \mathrm{~h} \\
3.27 \%\end{array}$ & $\begin{array}{c}\text { Above } 36 \mathrm{~h} \\
0 \%\end{array}$ & $\begin{array}{c}\text { Upto } 12 \mathrm{~h} \\
90.0 \%\end{array}$ & $\begin{array}{c}12-24 \mathrm{~h} \\
6.66 \%\end{array}$ & $\begin{array}{c}24-36 \mathrm{~h} \\
3.33 \%\end{array}$ & $\begin{array}{c}\text { Above } 36 \mathrm{~h} \\
0 \%\end{array}$ \\
\hline $\begin{array}{l}\text { Fetal dystocia } \\
\text { Fetal maldisposition } \\
\text { Fetal disease/monsters } \\
\text { Fetal death/emphysema } \\
\text { Total }\end{array}$ & & & $\begin{array}{l}48.95 \% \\
02.08 \% \\
14.58 \% \\
65.62 \%\end{array}$ & & $\begin{array}{l}35.71 \% \\
01.78 \% \\
04.46 \% \\
40.17 \%\end{array}$ & & & \\
\hline $\begin{array}{l}\text { Maternal dystocia } \\
\text { Narrow pelvis } \\
\text { Incomplete cervical dilation } \\
\text { Uterine torsion } \\
\text { Uterine inertia } \\
\text { Total }\end{array}$ & & & $\begin{array}{l}04.68 \% \\
08.33 \% \\
14.58 \% \\
06.77 \% \\
34.38 \%\end{array}$ & & $\begin{array}{l}02.67 \% \\
01.78 \% \\
53.57 \% \\
01.78 \% \\
59.82 \%\end{array}$ & & & \\
\hline
\end{tabular}




\section{Case analysis and discussion}

We made a retrospective analysis of 192 cases of dystocia in cattle and 112 cases of dystocia in buffalo presented at our referral center during the period 1996 to 2010. The animals were brought by both local owners and those living further afield, and included the local Rathi, non-descript and HF crossbred cows and Murrah and non-descript buffaloes. All these assisted cases were included in the analysis. The effect of parity on the proportion of the total dystocia cases presented was compared between different parities by the $\chi^{2}$ test. A ttest was used to compare the proportion of male and female calves in these assisted cases whereas the effect of time of presentation since onset of second stage of labor on fetal survival was compared by a z-test.

Fetal dystocia was common in cattle at our center comprising $65.62 \%$ of total cases presented, whereas maternal causes constituted $34.38 \%$ of total cases. Most of the cows presented were in their first parity (32.3\%) but nearly equal proportions (30.2\%) of cows were in second parity. A significantly lower $(\mathrm{P}<0.05)$ proportion of cows were presented in their third and subsequent parities. These findings are similar to a large number of previous studies analyzing calving data with reports of a high incidence of dystocia in heifers. ${ }^{20,34,35}$

In buffalo, maternal dystocia was common (59.82\%) compared to fetal dystocia (40.17\%), and uterine torsion was the most common cause of dystocia comprising $53.57 \%$ of the total cases of dystocia. Similar findings have been recently reported. ${ }^{244,245}$ A slightly higher proportion of buffalo were in their second parity (33.91\%) compared to first parity (30.3\%), but a significantly $(\mathrm{P}<0.05)$ lower proportion of buffaloes were presented in subsequent parities. This is in agreement with previous reports. 60,67

The effect of sex of calves on the proportion of cows or buffalo presenting dystocia was not significant $(\mathrm{P}>0.05)$. The time of presentation since onset of second stage labor had a significant $(\mathrm{P}<0.05)$ effect on fetal survival with a significantly higher $(\mathrm{P}<0.01)$ number of calves and buffalo calves being born alive when animals were presented within $12 \mathrm{~h}$ of onset of second stage of labor, irrespective of the type of dystocia and the correction procedure adopted. Beyond $36 \mathrm{~h}$, no calf or buffalo calf was born alive. Previous reports have observed that fetal survival is dependent on the time since onset of labor in assisted cases. ${ }^{24,43}$

Maternal causes, like narrow pelvis due to breeding at a younger age or pelvic fracture, incomplete cervical dilation and uterine inertia, were seen in $4.68 \%, 8.33 \%$ and $6.77 \%$ of cows whereas these were less frequent in buffalo $(2.67 \%, 1.78 \%$ and $1.78 \%$ of cases, respec- tively). The total incidence of fetal maldispositions in cattle and buffalo at our center was 48.95 and $35.71 \%$, respectively (Table 2). Fetal maldispositions in cattle comprised $48.95 \%$ of the total cases presented. Head and neck deviation and limb flexion were the most common cause for cranial presentation and only a small proportion of caudal presentations (3.12\%). The incidence of a dorsopubic position recorded in cattle at our center was $1.56 \%$. Other less frequent causes included fetal dropsical conditions (1.04\%), fetal monsters (1.04\%) and fetal emphysema (14.58\%). Similar findings have been previously recorded in clinical settings in different locations. ${ }^{27,43}$ In buffalo, fetal maldispositions were less frequent: only $33.92 \%$ of the total number of cases presented. The frequency of head/neck deviation and limb flexions was lower compared to that in cattle and caudal presentations were $6.25 \%$ of total dystocia. No case of fetal dropsy was seen in buffalo during the study period, and the frequency of fetal emphysema and monsters was 4.46 and $1.78 \%$, respectively. The incidence of uterine torsion was $14.58 \%$ in cattle and $53.57 \%$ in buffalo. Similar findings have been observed in previous studies in buffalo. $27,60,244,245$

Studies analyzing calving difficulties in cattle have critically addressed the importance of calf birth weight, sex of calf and fetal death as important fetal causes of dystocia in cattle. However, in a clinical setting, the fetal size relative to the birth canal and the fetal maldispositions appear to be of prime importance as they decide the course of action to be taken by the clinician. The method adopted to correct the dystocia and fetal survival depend upon the time of presentation of the animal after the onset of second stage of labor and the expertise available. It can be concluded that fetal origins of dystocia are common in first and second parity cows and buffalo and these are generally caused by an oversized fetus or fetal maldispositions; fetal monsters and fetal diseases being rare. The most common fetal maldispositions are limb flexion and head deviation. Fetal dystocia is less frequent in buffalo.

\section{References}

1. Lombard JE, Garry FB, Tomlinson SM, Garber LP. Impacts of dystocia on health and survival of dairy calves. J Dairy Sci 2007;90:1751-60.

2. Zaborski D, Grzesiak W, Szatkowska I. Factors affecting dystocia in cattle. Reprod Dom Anim 2009;44:540-51.

3. Uzamy C, Kaya I, Ayyilmaz T. Analysis of risk factors for dystocia in a Turkish Holstein herd. J Anim Vet Advances 2010;9:2571-7.
4. Meijering A. Dystocia and stillbirth in catlle: a review of causes, relations and implications Livestock Prod Sci 1984;11: 413-77.

5. Rajala PJ, Grohn YT. Effects of dystocia, retained placenta and metritis on milk yield in dairy cows. J Dairy Sci 1998;81: 3172-81.

6. Berry DP, Lee JM, Macdonald KA, Roche JR. Body condition score and body weight effects on dystocia and stillbirths and consequent effects on post calving performance. J Dairy Sci 2007;90:4201-11.

7. Dematawewa CMB, Berger PJ. Effect of dystocia on milk yield, fertility and cow losses and an economic evaluation of dystocia scores for Holstein cows. J Dairy Sci 1997;80:754-61.

8. Gaafar HMA, Shamiah SM, El-Hand MAA, et al. Dystocia in Friesian cows and its effects on postpartum reproductive performances and milk production. Trop Anim Health Prod 2011;43:229-34.

9. Berger PJ, Cubas AC, Kochler KJ, Healey MH. Factors affecting dystocia and early calf mortality in Angus multiparous cows and primiparous cows. J Anim Sci 1992;70:1775-86.

10. Casas E, Thallman RM, Cundiff LV. Birth and weaning traits in crossbred cattle from Hereford, Angus, Brahman, Boran, Tuli and Belgian Blue sires. J Anim Sci 2011;89: 979-87.

11. Jainudeen MR. Reproduction in the water buffalo. In: Morrow DA. Current therapy in Theriogenology. Philadelphia: WB Saunders Company; 1986. pp. 443449.

12. Kaushik SK, Mathur AC. Time of parturition and incidences of calving abnormalities in Murrah buffaloes. Indian J Anim Sci 2005;75:227-8.

13. Khan HM, Bhakat M, Mohanty TK, et al. Peripartum reproductive disorders in buffaloes - an overview. Vet Scan 2009;4:1-10.

14. Kodagali SB. Notes on Applied Bovine Reproduction. Part II. In: Kodagali SB. Bovine Obstetrics. Anand, Gujarat, India: Indian Society for Study of Animal Reproduction; 2003.

15. Agarwal SK, Tomer OS. Reproductive Technologies in the buffalo. Izatnagar, India: Indian Veterinary Research Institute Karnal India; 1998.

16. Mody M, Chauhan RAS, Shukla SP. Process of parturition in buffaloes. Indian J Anim Reprod 2002;23:141-3.

17. Ramasamy M, Singh M. A comparative study on normal and abnormal parturition in Karan fries cattle and Murrah buffaloes. In: Reproductive technologies for augmentation of fertility in livestock: Annual convention and national symposium, Nov.14-16,2002. Izatnagar: IVRI; 
2002. pp148-149.

18. Bendixen PH, Vilson B, Ekesbo I, Ekstrand DB. Disease frequencies in Swedish dairy cows. I Dystocia. Prev Vet Med 1986;4:307-16.

19. Johanson JM, Berger PJ. Birth weight as a predictor of calving ease and perinatal mortality in Holstein cattle. J Dairy Sci 2003;86:3745-55.

20. Mee JF, Berry DP, Cromie AR. Risk factors for calving assistance and dystocia in pasture-based Holstein Friesian heifers and cows in Ireland. Vet J 2011;187:189-94.

21. Holland MD, Speer NC, Lefever DG. Factors contributing to dystocia due to fetal malpresentation in beef cattle. Theriogenol 1993;39:899-908.

22. Nix JM, Spitzer JC, Grimes LW, et al. A retrospective analysis of factors contributing to calf mortality and dystocia in beef cattle. Theriogenol 1998;49:1515-23.

23. Sloss V, Johnston DE. The causes and treatment of dystocia in beef cattle in Western Victoria. Aust Vet J 1967;43:1320.

24. Majeed AF, Ali JB, Taha MB. A preliminary study on dystocia in local breed Iraqi cattle. Prev Vet Med 1989;7:219-23.

25. Ximenes FHB, Leite CR, Moscardini ARC, et al. Retrospective study of cases of dystocia in cattle at Veterinary Hospital of University of Brasilia from 2002 to 2009. Available from: http://www.originalprocess.it/wbc2010/AbstractCD/pdf/1196.p df

26. Phogat JB, Bugalia NS, Gupta SL. Incidence and treatment of various forms of dystocia in buffaloes. Indian $\mathrm{J}$ Anim Reprod 1992;13:69-70.

27. Purohit GN, Mehta JS. Dystocia in cattle and buffaloes. A retrospective analysis of 156 cases. Vet Practitioner 2006;7:31-4.

28. Ali AM. Studies on calving related disorders (dystocia, uterine prolapse and retention of fetal membranes) of the river buffalo (Bubalus bubalis) in different agro ecological zones of Punjab Province Pakistan. PhD Thesis Univ of Agic Pakistan. 2008. Available from: prr.hec.gov.pk/Thesis/203S.pdf

29. Smith GM, Laster DB, Gregory KE. Characterization of biological types of cattle 1. Dystocia and preweaning growth. J Anim Sci 1976;43:27-36.

30. Nelson LA, Beavers GD. Beef X beef and dairy $\mathrm{X}$ beef females mated to Angus and Chorolais sires. I Pregnancy rate, dystocia and birth weight. J Anim Sci 1982;54: 1138-49.

31. Van Wagoner HC, Ansotegui RP, Ropp MD, Lipsey RJ. The ease of heifers bred to Angus and Simmental sires selected for decreased dystocia. Proc Western Section Am Soc Anim Sci 2003;54:23-8.
32. Mc Clintock S, Poole R, Beard K, Goddard M. Cross breeding in dairy cattle: The effect on calving ease. Proceedings SLU. 2004. Available from: http://www-interbull.slu.se/bulletins/bulletin32/McClintoc k.pdf

33. Mee JF. Prevalence and risk factors for dystocia in dairy cattle: A review. Vet $\mathrm{J}$ 2008;176:93-101.

34. Rutter LM, Ray DE, Roubicek CB. Factors affecting and prediction of dystocia in Charolais heifers. J Anim Sci 1983;57: 1077-83.

35. Price TD, Wiltbank JN. Dystocia in cattle a review and implications. Theriogenol 1978;9:195-219.

36. Anderson P. Minimizing calving difficulty in beef cattle. 1992. Available from: http://www.thebeefsite.com/arti cles/658/minimizing calving difficulty in beef cattle.

37. Bellows RA, Genho PC, Moore SA, Chase CC. Factors affecting dystocia in Brahman cross heifers in sub tropical South Eastern United States. J Anim Sci 1996;74:1451-6.

38. Paschal JC, Sanders JO, Kerr JL. Calving and weaning characteristics of Angus, Gray Brahman, Gir, Indu-Brazil, Nellore and Red-Brahman sired F calves. J Anim Sci 1991;69:2395-402.

39. Meyer CL, Berger PJ, Koehler KJ, et al. Phenotypic trends in incidence of stiil birth for Holstein in the United States. J Dairy Sci 2001;84:515-23.

40. Ettema JF, Santos JEP. Impact of age at calving on lactation, reproduction health and income in first parity Holstein on commercial farms. J Dairy Sci 2004;87: 2730-42.

41. Ritchie HD, Anderson PT. Calving difficulty in Beef cattle: Part I. 2011. Available from: http://www.iowabeefcenter.org

42. Khammas DJ, Al-Hamedawi TM. Clinical investigation of bovine dystocia in Iraq. Indian Vet J 1994;71:464-8.

43. Wehrend A, Reinic T, Herfen K, Bostedt H. Fetotomy in cattle with special references to post operative complications: an evaluation of 131 cases. Dtsch Tierarztl Wochenschr 2002;109:56-61.

44. Bennett GL, Gregory KE. Genetic (co) variances for calving difficulty score in composite and parental populations of beef cattle: 1. Calving difficulty score, birth weight, weaning weight and postweaning gain. J Anim Sci 2001;79:45-51.

45. Garrousi TM. Effects of different factors in dystocia due to foetal disposition. 23rd World Buiatrics Congr Canada. 2004. pp 1598. Available from: http://www.ivis.org/proceedings/wbc/wbc2 004/abstr_601_700.pdf

46. Youngquist RS. Parturition and dystocia.
In: Youngquist RS. Current therapy in large animal theriogenology. Philadelphia: W.B. Saunders Co.;1997. pp. 309-324.

47. Zhang WC, Nakao T, Moriyoshi M, et al. Relationship of maternal plasma progesterone and estrone sulfate to dystocia in Holstein Friesian heifers and calves. J Vet Med Sci 1999;61:909-13.

48. Momont $\mathrm{H}$. Bovine reproductive emergencies. Vet Clin Food Anim Pract 2005;21:711-27.

49. Laster DB, Glimp HA, Cundiff LV, Gregory KE. Effects of Early Weaning on Postpartum Reproduction of Cows. J Anim Sci 1973;36:695.

50. Arthur GH, Noakes DE, Pearson H, Parkinson TJ. Veterinary Reproduction and Obstetrics. Philadelphia: W.B. Saunders Co. Limited; 1999.

51. Ménissier F. General survey of the effect of double muscling on cattle performance. In: Ménissier F, King JWB. Muscle hypertrophy of genetic origin and its use to improve beef production. The Hague: Martinus Nijhoff Publishers; 1982. pp. 2353.

52. Fiems LO, de Campeneere W, Van Caelenbergh, Bougue CV. Relationship between dam and calf characteristics with regard to dystocia in Belgian Blue double-muscled cows. Anim Sci 2001;72: 389-94.

53. Sane CR, Luktuke SN, Deshpande BR, et al. A text book of reproduction in farm animals (Theriogenology). India; Varghese Publishing House; 1982.

54. Nelson L A, Huber DA. Factors influencing dystocia in Hereford dams. J Anim Sci 1971;33:1137.

55. Cole JB, Goodling RC, Wiggams GR, van Raden PM. Genetic evaluation of calving ease for Brown swiss and Jersey bulls from purebred and crossbred calvings. J Dairy Sci 2005;88:1529-39.

56. Young LE, Sinclair KD, Wilmut I. Large offspring syndrome in cattle and sheep. Rev Reprod 1998;3:155-63.

57. Maxfield EK, Sinclair KD, Dolman DF, et al. In vitro culture of sheep embryos increases weight, primary fibre size and secondary to primary fibre ratio in fetal muscle at day 61 of gestation. Theriogenol 1997;47:376.

58. Hyttel P, Viuff D, Laurincik J. Risks of in vitro production of cattle and swine embryos: aberrations in chromosome numbers, ribosomal RNA gene activation and perinatal physiology. Human Reprod 2000;15:87-97.

59. Nanda AS, Brar PS, Prabhakar S. Enhancing reproductive performance in dairy buffalo: major constraints and achievements. Reprod Suppl 2003;61:27- 
36.

60. Srinivas M, Sreenu M, Lakshmi RN, et al. Studies on dystocia in graded Murrah buffaloes: a retrospective study in a cow. Buff Bull 2007;26:40-5.

61. Ocampo AR. Further studies on the breeding habbits of the carabao. Phillip Agric 1989;28:286-307.

62. El-Sheikh AS. The reproductive performance of the buffalo in the UAE. Indian $\mathrm{J}$ Dairy Sci 1967;20:89-95.

63. Arya VV, Desai RN. Growth rate and its relationship with weight and age at first calving in buffaloes maintained on military farms. Indian Vet J 1996;46:61-8.

64. Fahimuddin M. Reproduction in the water buffalo. In: Fahimuddin M. Domestic water buffalo. New Delhi: Oxford and IBH;1975. pp 227-283.

65. Tonhati H, Vasconcellos FB, Albuquerque LG. Genetic aspects of productive and reproductive traits in a Murrah buffalo herd in Sao Paulo Brazil. J Anim Bred Genetics 2000;117:331-6.

66. Seno L0, Cardoso VL, El Faro L, et al. Genetic parameters for milk yield, age at first calving and interval between first and second calvings in milk of Murrah buffaloes. Livestock Res Rural Dev 2010. Available from: http://www.lrrd.org/lrrd22/ 2/seno22038.htm

67. Thiruvenkadan AK, Panneerselvam S, Rajendran R. Non genetic and genetic factors influencing growth performance in Murrah buffaloes. South Afr J Anim Sci 2009;39:102-6.

68. Newman S, Mac Neil MD, Reynolds WL, et al. Fixed effects in the formation of a composite line of beef cattle: I experimental design and reproductive performance. J Anim Sci 1993;71:2026-32.

69. Correa MT, Erb H, Scarllet J. Path analysis for seven post partum disorders of Holstein cows. J Dairy Sci 1993;76:130512.

70. Heins BJ, Hansen LB, Seykora AJ. Calving difficulty and still births of pure Holstein versus crossbreds of Holstein with Normande, Montbeliarde and Scandinavian Red. J Dairy Sci 2006;89: 2805-10.

71. Gregory KE, Echternkamp Se, Dickerson JE. Twining in cattle III. Effects of twinning on dystocia, reproductive traits, calf survival, calf growth and low productivity. J Anim Sci 1990;68:3133-44.

72. Hossein-Zadeh NG. The effect of twinning on milk yield, dystocia, calf birth weight and open days in Holstein dairy cows of Iran. J Anim Physiol Anim Nutr (Berl) 2010;94:780-7.

73. Gregory KE, Echternkamp SE, Cundiff LV. Effects of twinning on dystocia, calf survival, calf growth, carcass traits and cow productivity. J Anim Sci 1996;74:1223-33.

74. Echternkamp SE, Gregory KE. Effects of twinning on gestation length, retained placenta and dystocia. J Anim Sci 1999;77: $39-47$.

75. Rao KS, Rao KB, Raju KGS. Birth of heterozygous twins in an Ongole crossbred cow. Indian J Anim Res 2000;34:67-72.

76. Kirkpatrick BW. Management of twinning cow herds. J Anim Sci 2002;80:14-8.

77. Cobanoglu 0. Twinning in cattle: Desirable or undesirable? J Biol Environ Sci 2010;4:1-8.

78. Bicalho RC, Galvao KN, Cheong SH, et al. Effect of stillbirths on cow survival and reproduction performance in Holstein dairy cows. J Dairy Sci 2007,90:2797-803.

79. Phogat JB, Singh P, Gupta SL. Observations on dystocia due to emphysematous fetuses in buffaloes. Indian J Anim Reprod 1993;14:65.

80. Craig JF. Fleming's Veterinary Obstetrics. Fourth Edition. Bailliere. London: Tindall and Cox; 1930.

81. Singla VK, Sharma RD. Analysis of 188 cases of dystocia in buffaloes. Indian Vet J 1992;69:563-4.

82. Laughton KW, Fisher KRS, Halina WG, Partlow GD. Schistosoma reflexus syndrome : a heritable defect in ruminants. Anat Histol Embryol 2005;34:312-8.

83. Citek J, Rehout V, Hajkova J. Congenital disorders in the cattle population of the Czech Republic. Czech J Anim Sci 2009; 54:55-64.

84. Knight RP. The occurrence of schistosomus reflexus in bovine dystocia. Aust Vet J 1996;73:105-7.

85. Morton DH, Cox JE. Bovine dystocia: a survey of 200 cases met within general practice. Vet Rec 1968;82:530-7.

86. Cavalieri J, Farin PW. Birth of a Holstein freemartin calf co twinned to a schistosomus reflexus fetus. Theriogenol 1999;52: 815-26.

87. Sarma RB. A case of schistosoma reflexus in a calf. Indian Vet J 1949;25:217-8.

88. Szonyi S. Bovine monstrosity. Can J Comp Med 1956;20:343-4.

89. Fatimah I, Bangso TA, Chooi KF. Schistosomus reflexus in a bovine calf: a case report. J Vet Malays 1981;13:40-2.

90. Bugalia NS, Verma SK, Khar SK, Khan MZ. Schistosomus reflexus in a Haryana cow. Haryana Vet 1982;21:38-40.

91. Higham DA. Schistosmus reflexus Vet Rec 1987;121:455.

92. Holt K. Schistosomus reflexus: a cluster of cases Vet Rec 1987;121:155.

93. Jackson PG. Schistosomous reflexus Vet Rec 1987;121:235-6.

94. Balasubramaniam S, Thilagar S, Kathiresan D, Pattabiraman SR. A case report on schistosoma reflexus with brachygnathia inferior in a calf. Indian Vet J 1961;68:567-8.

95. Paolichhi FA. A case of schistosoma reflexus in an Aberdeen Angus calf. Indian Vet J 1992;69:738-41.

96. Bezek DM, Frazer GS. Schistosomus reflexus in large animals. Compend Contin Edu Vet Pract 1994;16:1393-4.

97. Jana D, Ghosh M. Dystocia due to fetal monster with schistosoma reflexus and ectopic viscera - A case report. Indian Vet J 2001;78:333-4.

98. Rao AVN, Sreemannarayana 0 . Schistosoma reflexus in a buffalo conjoined twin. A case report. Indian Vet $\mathrm{J}$ 1984;61:80.

99. Sastry JS, Murthy S. Incidence of schistosoma reflexus monstrosity in Indian water buffalo. Indian Vet J 1984;61:1084.

100. Bishnoi BL, Gupta AK, Kohli IS. A case report of schistosomus reflexus in Indian buffaloes. Indian Vet J 1987;11:119.

101. Murthy KK, Murthy PRK, Prasad V, et al. Dystocia due to schistosoma reflexus in a she-buffalo - a case report. Indian Vet $\mathrm{J}$ 1999;76:733-4.

102. Chandolia RK, Chander S, Kumar A, Singh P. Sistocormus fissipinalis monster in a buffalo. Indian J Anim Reprod 2003; 24:176.

103. Herr S. Techniques for fetotomy on schistosomus reflexus calves. Vet Med Small Anim Clin 1979;74:1009-12.

104. Bugalia NS, Chander S, Chandolia RK, et al. Monstrosities in buffaloes and cows. Indian Vet J 1990;67:1042-3.

105. Bezek DM, Williams JF, Biller DS. What is your diagnosis? Perosomus elumbis in a bovine fetus. J Am Vet Med Assoc 1994; 205:1685-6.

106. Son JM, Yong HY, Lee DS, et al. A case of perosomus elumbis in a Holstein calf. $\mathrm{J}$ Vet Med Sci 2008;70:521-3.

107. Kulasekar K, Chandrahasan C, Seshagiri VN. Dystocia due to persomus elumbis monster in a she-buffalo (Bubalus bubalis). Indian J Anim Reprod 1996;17: 68.

108. Jana D, Mousumi J. Dystocia due to perosomus elumbis foetal monster with breech presentation in a buffalo. Indian $\mathrm{J}$ Field Vet 2010,6:73-5.

109. Whitlock BK, Kaiser L, Maxwell HS. Heritable bovine fetal abnormalities. Theriogenol 2008;70:535-49.

110. Gadgil BA. Dicephalous monstrosity in a buffalo. Indian Vet J 1967;44:255.

111. Saxena OP, Prakash P. Thoracopagus conjoined twins in cattle - a case report. Indian Vet J 1986;63:470-2.

112. Pandey GS, Shandoma MN. A case report of bovine conjoined twins. Indian Vet $\mathrm{J}$ 1989;66:869-70.

113. Bakshi SA, Tandle MK, Aher VD, et al. 
Dicephalic monster in a cross bred cow. Indian J Anim Reprod 1992;13:93.

114. Bakshi BL, Sharma SS, Gupta AK. Dicephalus monster in a buffalo calf (Bubalus bubalis) Indian J Anim Reprod 1992;13:95.

115. Bishnoi BL, Sharma SS, Gupta AK, et al. Dicephalus monster in a buffalo calf. Indian Vet J 1992;13:95.

116. Thakre AG, Sarode DB, Sahare JS, Kaikini AS. Dicephlus diphygus monster in a Nagpuri buffalo. Indian $\mathbf{J}$ Anim Reprod 1992;13:200.

117. Chauhan KS, Verma HK. A case of dystocia due to diplopagus monster in a buffalo. Indian J Anim Reprod 1995;16:75.

118. Kumar S, Prasad S, Sharma V. Dicephalus tetrapus tetrabrachius monster in a graded Murrah buffalo. Indian J Anim Reprod 1999;20:171.

119. Bugalia NS, Biswas RK, Sharma RD. Dicephalus monster in an Indian water buffalo (Bubalus bubalis). Indian J Anim Reprod 2001;22:196-7.

120. Kasiraj R, Mutharao MS, Ranga Reddy NS, Misra AK. Conjoined monozygotic twins in a buffalo - A case study. Indian J Anim Reprod 2001;22:191.

121. Chandrahasan L, Krishna KK, Selvaraju $\mathrm{M}$, et al. Dystocia due to dicephalus monostomus monster in a cross bred cow. Indian J Anim Reprod 2003;24:175.

122. Roberts SJ. Veterinary Obstetrics and Genital Diseases. New Delhi: Indian ed CBS Publishers; 1986.

123. Sinha SN, Akhtar MH, Roy GP, Kumar Y. Dystocia in a buffalo due to foetal monster (conjoined twin). Indian Vet $\mathrm{J}$ 1984;61:1085.

124. Sharma RD, Dhaliwal GS, Prabhakar S. Fetotomy in dystocias due to monstrosities in buffaloes. Indian $\mathrm{J}$ Anim Reprod 1992;13:188-190.

125. Sahu S. A cephalothoracopagus disymmetros buffalo calf. Indian Vet $\mathrm{J}$ 1968;46:1046-7.

126. Sreemannarayana 0, Cristopher KJ, Raju G, Narsimhamurti N. Double faced (Diprosopus) buffalo calf. Indian Vet $\mathrm{J}$ 1980;57:512-3.

127. Sharma A, Sharma S, Vasistha NK. A diprosopus buffalo neonate: A case report. Buff Bull 2010;29:62-63.

128. Parikh MC. Double headed foetus. Indian Vet J 1931;7:262-3.

129. Subbarayundie MV. Double headed monstrosity. Indian Vet J 1934;10:241.

130. Eichler VB, Krogh JK. Development abnormalities of a new born two headed calf, with special reference to the anterior vessels and compound heart. Vet Pathol 1985;22:189-91.

131. Mc Girr WJ, Partlow GD, Fisher KR. Two headed, two necked conjoined twin calf with partial duplication of thoracoabdominal structures. Role of blastocyst hatching. Anat Rec 1987;217:196-202.

132. Wakuri H, Mori T, Mutoh K. Arnold-Chiari malformation and associated abnormalities in dicephelic newborn calf. Okajimas Folia Japonica 1990;67:339-50.

133. Adsul PB, Velhankar RD, Dhande PL). Dicephalic dicardiac monster in a Dangi cow. Indian J Anim Reprod 1192;13:201-2.

134. Madarame H, Ito N, Takai S. Dicephalus Arnold-chiari malformation and spina bifida in a Japanese black calf. Zentralbl Veterinarmed A 1993;40:155-60.

135. Madarame H, Takai S, Ito N. Two headed, two necked conjoined twin calf with Arnold-chiari malformation in a Japanese calf. Anat Histol Embryol 1994;23:275-80.

136. Saha S, Sirkar CR, Jewari M. Dicephalus ischiopagus monster in a cross bred cow. Indian J Anim Reprod 1996;17:77.

137. Khan MZ, Islam R, War BA. Dystocia due to dicephalus distomus monster in a crossbred Jersey cow. Indian J Anim Reprod 2007;28:86-7.

138. Khasatiya CT, Patel DM, Dabhi DM, Chaudhari PP. Dystocia due to Dicephalus Dipagus monster in a Dangi cow. Indian J Anim Reprod 2008;29:224-5.

139. Buck BC, Zoeller M, Baumgartner W, Distt 0 . A rare occurrence of dicephalus scoliosis and complex heart anomalies in a male black and white German Holstein calf. Berl Munch Tierarztl Wochenschr 2009;122:116-20.

140. Rekhi BS. An unusual fetus in a buffalo cow. Indian Vet J 1939;15:426.

141. Reddy DS, Balasubramanyan R. A case of Bicephalus monstrosity in a buffalo calf. Indian Vet J 1950;26:421-2.

142. Jothi RS. Freak of nature. Indian Vet J 1956;32:304-5.

143. Majeed MA, Hussain SS, Har G). The structure of a double headed buffalo calf (Dicephalus dipus dibrachius) Vet Rec 1971;88:393-5.

144. Rao AVN, Sastry S, Joseph G, et al. Incidence of monosomian monstrosity in Indian water buffalo. Indian Vet $\mathbf{J}$ 1971;48:67-8.

145. Rao V, Jagannatha N, Kottaya K. Incidence of Isosomian monstrosity in Indian water buffaloes. Indian Vet J 1976;53:728.

146. Bishnoi BL, Kohli IS, Singh K. A case of double monstrosity in a she-buffalo. Indian Vet J 1984;61:901-2.

147. Dhingra SO, Hukeri VB, Deshpande BR. A study on double monster and its internal organs in a buffalo. Indian Vet $\mathrm{J}$ 1984;61:346.

148. Markandeya NM, Pargaonkar DR, Bakshi SA. Dicephalus monster in a Murrah buffalo - a case report. Indian J Anim Reprod 1989;19:176-8.
149. Panchal KM, Bhayani DM, Pandya S, et al. A note on dicephalic monster in a Surti buffalo. Indian $\mathrm{J}$ Anim Reprod 1990;11:160-2.

150. Bhayani DM, Panchal KM, Pandya S, Bage AS. An anatomical note on skeleton of dicephalic monster of Surti buffalo. Indian Vet J 1991;68:987-8.

151. Tandle MK, Suresh SH. A monostomus dicephalus male buffalo calf monster. Indian J Anim Reprod 1993;14:128.

152. Sharma A, Singh M, Sood P. Dystocia due to fetal monster in a buffalo - A case report. Indian J Anim Reprod 1996;17:74.

153. Suresh K, Prasad S, Sharma V. Dicephalus tetrapus tetrabrachius monster in a graded Murrah buffalo. Indian J Anim Reprod 1999;2:171.

154. Raju KGS, Rao KS, Reddy VSC, Sharma GP. Dicephalus bialanticus monster in a buffalo. Indian J Anim Reprod 2000;21:81.

155. Thirumalish T, Azeemulla HR. Dicephalus dibrachius monster in a buffalo - A case report. Indian Vet J 2001;78:355-6.

156. Dass J. Double headed monstrosity. Indian Vet J 1931;7:260-1.

157. Otonari S, Nakai M, Yamaguchi R, et al. Five cases of cranial duplication in a calf. J Vet Med Sci 1993;55:493-5.

158. Rao MN, Murthy TSN. A case report of bovine conjoined twin. Indian Vet $\mathrm{J}$ 1994;71:1242.

159. Bahr C, Beineke A, Drogemuller C, Distt 0 . Diprosopus in calves of different breeds. Dtsch Tierarztl Wochenschr 2004;111:154-8.

160. Tacal JV. Cephalic dichotomy in a carabao (Bubalus bubalis) calf. Indian Vet $\mathrm{J}$ 1967;44:256.

161. Rao VN, Prakash P, Joshi HC. Conjoined twins in a bovine foetus. Indian Vet $\mathrm{J}$ 1986;63:871-2.

162. Abraham J, Bihu S, Raj IV, Lakshmanan B. Dicephalic monster in a heifer Indian J Anim Reprod 2007;28:109-11.

163. Saleem M, Dadke RS, Dharmadhikari VG. Dicephalus monster in a buffalo - A case report. Indian Vet J 1996;73:1181-2.

164. Padile RD, Yadav GV, Aher VD, et al. Epitheliogenesis imperfecta in a Murrah buffalo calf - A case report. Indian Vet $\mathbf{J}$ 1961;78:658.

165. El-Shiekh H, Hegab A0, Zaabel SM. Dicephalus Atlodymus monster associated with hydrops amnii in a buffalo cow. Vet Res 2010;3:46-8.

166. Velhankar DP, Deshpande BR, Hadi MA, et al. Occurence of Gastrothoracodidymus octopes twin monsters in buffaloes. Indian Vet J 1968;45:823-9.

167. Nauriyal DC, Pandey NN. Bovine double monster in a buffalo. Indian Vet $\mathrm{J}$ 1979;56:976.

168. Urankar RM, Chhonker SV Gangaprai PM. 
Conjoined twin monstrosity in a buffalo. Indian J Anim Reprod 1994;15:165.

169. Kohli RN, Kumar V, Rama Prasad B, et al. Successful surgical correction of a female double monster buffalo calf. Indian Vet $\mathrm{J}$ 1980;57:416-8.

170. Naidu RS, Suresh Kumar RV, Kumar BVD. A case of sternophagus buffalo fetuses. Indian Vet J 1996;73:881-2.

171. Selvaraju M, Kathiresan D, Veerapandian C. Dystocia due to conjoined twin monster in a buffalo - A case report. Indian Vet J 2002;79:721-2.

172. Jerome A, Sarath T, Arunmozi N. Dystocia due to conjoined twin monster in a buffalo. Buff Bull 2010;29:229-30.

173. Mahalingam S. Conjoined buffalo twins. Indian Vet J 1968;42:1047-8.

174. Kondala Rao PD, Rao AVN, Sreemannarayan 0. A symmetrical conjoined twin with three parasitic limbs in a Zebu calf. Indian Vet J 1997;74:256.

175. Schulze U, Distt 0. Case Report: Arhinia and Cyclopia in a German Fleckvieh calf. Dtsch Tierarztl Wochenschr 2006;113: 236-9.

176. Thakur SB. Dipygus monstrosity in a calf. Indian Vet J 1988;65:440.

177. Bugalia NS, Saigal RP, Sharma RD, Dugwekar YG. Diplopygus sternopagus monster in an Indian water buffalo (Bubalus bubalis). Indian J Anim Reprod 1985;6:102-4.

178. Antoine D, Murugavel K, Alphonse RMBD, et al. Monocephalus dipygus monster in a buffalo: a case report. Indian J Anim Reprod 1997;8:166.

179. Markandeya NM, Panchabhai VS, Salunke VM, Bhikane AV. A case of dystocia due to campylorrachis monster in a cow. Indian J Anim Reprod 1998;19:163.

180. Chidester FE. Cyclopia in mammals. The Anat Rec 1914;8:355-66.

181. Mohanty BV. Congenital malformation in bovines. Incidence of cyclopia. Indian Vet J 1968;45:526-7.

182. Chakraborti A, Ganguli JL. Incidence of cyclopia prostomus arrhynchus in an indigenous cow (Bos indicus). Indian Vet J 1977;54:327-8.

183. Venu R, Reddy PCS, Dhanalakshmi N. Cyclopia in a Jersey cross bred calf - a case report. Indian Vet J 2001;78:657.

184. Ozcan K, Gurbulack K, Takci I, et al. A typical cyclopia in a brown Swiss cross calf: a case report. Anat Histol Embryol 2006;35:152-4.

185. Schulze U, Distt 0. Case Report: Arhinia and Cyclopia in a German Fleckvieh calf. Dtsch Tierarztl Wochenschr 2006;113:236-9.

186. Ayyar AR. A case of congenital hydrocephalic monstrosity. Indian Vet $\mathrm{J}$ 1934;10:241-2.
187. Raju VS. A case of monstrosity in a calf. Indian Vet J 1939;16:648.

188. Srinivasan V. Breech presentation of a Megalocephalus monster in a cow. Indian Vet J 1940;17:160-1.

189. Allen JG. Congenital cerebellar hydroplasia in Jersey calves. Aust Vet J 1977;54:173-5.

190. Cristoferson LA, Leech RW, Hazen GA. Bovine hdyrocephelus in North Dakota: a survey and morphologic study. Surg Neurol 1977;7:165-70.

191. Mouli SP. Surgical correction of congenital external hydrocephalus in a bull calf. Indian Vet J 1987;64:696-8.

192. Balasubramaniam S, Ashokan SA, Seshagirl VN, Pattabiraman SR. Congenital internal hydrocephalus in calf. Indian Vet J 1997;74:446-7.

193. Sharda R, Ingole SP. Congenital bilateral hydrocephalus in a Jersy cow calf - a case report. Indian Vet J 2002;79:965-6.

194. Kumaresan A, Garg A, Mahapatra US, et al. Dystocia due to hydrocephalus in a buffalo calf. Indian J Anim Reprod 2003;24:82.

195. Purohit GN,Gaur M, Sharma A. Dystocia in Rathi cows due to congenital hydrocephalus. Indian J Anim Reprod 2006;27: 98-9.

196. Windsor PA, Cavanagh TA, Tammen I. Hydrops fetalis associated with pulmonary hydroplasia in Dexter calves. Aust Vet J 2006;84:278-81.

197. Singh AK, Brar PS. Hydrocephalus fetus: a rare case of fetal dystocia in a cow. Indian J Anim Reprod 2008;29:124.

198. Buck BC, Schnek H, Imbschweiler I, et al. A case of congenital high grade hydrocephalus internus and Dandy-Walker syndrome in a black and white German Holstein calf. Dtsch Tierarztt Wochenschr 2009;116:220-26.

199. Smolec 0, Kos J, Vnuk D,et al. Multiple congenital malformation in a Simmental female calf: a case report Veterinarni Medicina 2010;55:194-8.

200. Rao CRV, Sreeramula P, Krishnamurthy C, Rao AVR. A buffalo hydrocephalus calf removed by caesarotomy under field conditions Indian Vet J 1975;52:586-8.

201. Bhandari RM, Kadu MS, Belorkar PM, Marudwar SW. Obstetrical management of hydrocephalic foetus in buffaloes: a report of two cases. Indian Vet $\mathrm{J}$ 1978;55:1001-2.

202. Salunke SP, Amle MB, Zambre PC. Dystocia due to hydrocephalus in Pandharpuri buffalo. Indian $\mathrm{J}$ Anim Reprod 2001;22;96.

203. Nandakumar S, Ramachandra KM, Mohan S, Anil Kumar TV. Pathology of bovine congenital external hydrocephalus. Indian Vet J 1999;76:847-9.
204. Vidya Sagar P, Veni K, Sai Krishna KS Vadde KS. Dystocia due to fetal ascites with wry neck in a graded murrah buffalo. A case report. Buff Bull 2010;29:73-4.

205. Gallagher DS, Lewis BC, De Donato M, et al. Autosomal trisomy 20 in a malformed bovine fetus. Vet Pathol 1999;36:448-51.

206. Shukla SP, Nema SP, Pandey AK, Garg UK. Dystocia due to bull dog calf in a she buffalo. Buff Bull 2007;26:104-5.

207. Singh B, Singh SV, Singh KP. Dystocia due to fetal anasarca in a buffalo. Indian J Anim Reprod 2007;28:90-1.

208. Prasad MC, Srivastava SC, Yadav KP, Mohan K. Foetal hydrops in cattle. Indian Vet J 1968;45:995-6.

209. Pandit RK, Singh V. Dystocia caused by severe fetal hydroperitoneum in a local cow. Indian J Anim Reprod 1990;11:76-7.

210. Rajasundaram RC, Selvaraju S, Ayyappan S. Dystocia due to fetal ascites in cow - a case report. Indian Vet J 1998;75:165-7.

211. Honparkhe M, Kumar A, Gandotra VK. Dystocia due to accumulation of fluid in peritoneal cavity and intestines of fetus in a cross bred cow. Indian J Anim Reprod 2003;24:83-4.

212. Iyengar RK. A case of dystocia due to ascites of the fetus. Indian Vet $J$ 1943;19:326-7.

213. Shastry AP, Rao RL, Christopher KJ. Foetal dystocia in buffalo. Indian Vet $\mathrm{J}$ 1975;52:728-9.

214. Iyer MRK. Hydro allantois in a she-buffalo caused due to dropsy of the fetus. A case report. Indian $\mathrm{J}$ Anim Reprod 1986;7:144-5.

215. Devanathan TG, Asokan SA Veerapandian, Sheshagiri VN. A note on fetal ascites with mild anasarca in buffalo. Indian J Anim Reprod 1990;11:68.

216. Nanda AS, Nowshahri MA, Sharma RD. Some studies on an ascitic fetus causing dystocia in a buffalo. Indian $\mathbf{J}$ Anim Reprod 1991;12:105-6.

217. Phogat JB, Bugalia NS, Bhardwaj RM. Dystocia due to fetal hydroperitoneum in a Murrah buffralo. Indian J Anim Reprod 1991;12:104-5.

218. Chaudhary S, Singh H, Sharma VK, Dabas YPS. Dystocia due to foetal ascites in a Murrah buffalo. A case report. Indian J Anim Reprod 1996;17:71-2.

219. Subramaniam A, Sundar Singh JSD. Dystocia due to cystic enlargement of fetus in a buffalo. Indian Vet J 1986;62:70.

220. Shanta YG, Phay CP. Monstrosity in a calf. Indian Vet J 1936;13:158-9.

221. Sitaramamurty G. A case of abnormal fetal development. Indian Vet $\mathrm{J}$ 1946;22:352.

222. Gupta PP, Pathak MP, Singh B. A note on an unusual case of monstrosity in a calf. Indian Vet J 1978;55:350. 
223. Maiti SK, Das A, Samanta D. Bull dog foetal monster in cattle. Indian Vet $\mathrm{J}$ 1994;71:193-4.

224. Kumar A, Honparkhe M, Dhaliwal GS. Dystocia due to bull dog calf in a crossbred cow. Indian J Anim Reprod 2007;28:84-5.

225. Rao Narshimha AV, Janakiramayya M. Achondroplasia in buffalo species. Indian Vet J 1995;72:992-3.

226. Singh J, Mideksa B, Pawde AM, Deori S. Fetal arthrogryposis causing dystocia in a pluriparous buffalo. Buff Bull 2008; 27:263-4.

227. Mee JF. Holocardius amorphous totalis in two Friesian cows carrying natural and induced twins. Vet Rec 1990;127:304-7.

228. Mohan CM, Mada-Balasubramaniam S, Subramaniam A. Obstetrical management of camphylorrachis foetal monstrosity in a cow - a case report. Indian Vet $\mathrm{J}$ 1996;73:1076-7.

229. Vyas KN, Mudholkar DR. A case of acephalus acardiacus monstrosity in an Indian buffalo. Indian Vet J 1971;48:61920.

230. Phogat JB, Singh S, Bugalia NS, Gupta SL. Holocardius amorphous in corpus uteri of a buffalo. Indian J Anim Reprod 1992;13:198-99.

231. Dhami AJ, Panchal MT, Kavani FS. Dystocia due to holoacardius acephalic (assymetrical conjoined twin) monster in a buffalo. Indian J Anim Reprod 2000;21:162-4.

232. Prabhakar S, Singh P, Nanda AS, Rana JS. Muscular pseudohypertophy in a buffalo fetus - A case report. Indian Vet $\mathrm{J}$ 1995;72:997-8.

233. Kumar D, Dilip Muralikrishna BV, Ramakrishna V. Dystocia due to foetal lipomatosis in a she-buffalo. Indian Vet $\mathrm{J}$ 1997;74:687-8.

234. Prabhakar S, Gandotra VK, Honoparkhe M. Dystocia due to muscular hypertrophy and excessive accumulation of abdominal fat in a buffalo fetus. Indian $\mathrm{J}$ Anim Reprod 2003;24:80-1.

235. Ghuman SPS, Nazir G, Ganie MA, Phawa B. Delivery of arthrogryposis-scoliosis fetus in a buffalo through partial fetotomy. Indian J Anim Reprod 2009;30:92.

236. MacLachlan NJ, Osburn BI. Blue tongue virus induced Hydranencephaly in cattle. Vet Pathol 1983;20:563-73.

237. Yeruham I, Michael M, Perl S. An unusual congenital malformation in a calf with serological evidence of fetal bovine viral diarrhea virus infection. Acta Vet Scand 2001;42:425-8.

238. Charan K, Gill BS, Ramuru M, Parihari NS. Mesothelioma in a bovine fetus associated with dystocia in the cow. Indian Vet J 1974;51:572-3.
239. Vandeplassche M. Dystocia. In: Mckinnon AD, Voss J. Equine Reproduction. Philadelphia: Lea and Febriger; 1993. pp 578-587.

240. Frazer GS. Dystocia and fetotomy. In: Samper JC, Pycock JF, Mc Kinnon AO. Current therapy in equine reproduction. Missouri: Saunders Elsevier; 2007. pp 417-434.

241. Scanlon PF. Orientation of cattle fetuses in utero in relation to stage of pregnancy. J Dairy Sci 1975;58:571-3.

242. Menard L. The use of clenbuterol in large animal obstetrics: manual correction of Bovine dystocias. Can Vet J 1994;35:28992.

243. Mudasir Q, Shukla SP, Noma SP, et al. Dystocia due to lateral deviation of the head and fetal emphysema in a she buffalo. Buffalo Bull 2010;29:78-80.

244. Purohit GN, Barolia Y, Shekher C, Kumar P. Maternal dystocia in cows and buffaloes: a review. Open J Anim Sci 2011;1: 41-53.

245. Purohit GN, Barolia Y, Shekhar C, Kumar P. Diagnosis and correction of uterine torsion in cattle and buffaloes. Raksha Techn Rev 2011;1:11-7. 